\title{
Erratum to: Use of porous high-density polyethylene grafts in open rhinoplasty: no infectious complication seen in spreader and dorsal grafts
}

Shabahang Mohammadi ${ }^{\dagger}$, Mohammad Mohseni ${ }^{* \dagger}$ and Masoumeh Eslami

The original version of this article [1] unfortunately contained a mistake. The author list was incorrect. The correct author list is: Shabahang Mohammadi, Mohammad Mohseni and Masoumeh Eslami.

\begin{abstract}
Authors' contributions
SM has made substantial contributions to concept design, study design, and acquisition of data; and performed the surgeries (open rhinoplasty). MM (corresponding author) has made substantial contributions to concept design, study design, and acquisition of data. ME has made substantial contributions to concept design, study design, acquisition of data, analysis of data, and writing the manuscript. She also participated in the surgeries (rhinoplasty). HA participated in coordination of the study; and acquisition and analysis of data. ME participated in coordination of the study; and acquisition and analysis of data. All authors read and approved the final manuscript.
\end{abstract}

Received: 20 July 2015 Accepted: 20 July 2015

Published online: 02 October 2015

\section{Reference}

1. Mohammadi S, Mohseni M, Eslami M, Arabzadeh H, Eslami M. Use of porous high-density polyethylene grafts in open rhinoplasty: no infectious complication seen in spreader and dorsal grafts. Head \& Face Medicine. 2014;10:52.

\footnotetext{
* Correspondence: mohsenient@yahoo.com

${ }^{\dagger}$ Equal contributors

Ear Nose Throat (ENT) and Head and Neck Surgery Research Center, Hazrat RasoulAkram Hospital, Iran University of Medical Sciences, Sattarkhan St,

Submit your next manuscript to BioMed Central and take full advantage of:

- Convenient online submission

- Thorough peer review

- No space constraints or color figure charges

- Immediate publication on acceptance

- Inclusion in PubMed, CAS, Scopus and Google Scholar

- Research which is freely available for redistribution 